Dr. Clarke is an active member of various committees of the British Psychological Society's Division of Professional Psychologists, and during 1954 he acted as secretary of the Society's Working Party on Mental Deficiency which prepared the memorandum of evidence submitted to the Royal Commission. His book Mental Deficiency: the Changing Outlook is considered to be one of the best on mental deficiency by an English-speaking psychologist, and he has contributed many papers to learned journals on clinical problems relating to intelligence, personality, learning in imbeciles and their employability, on social and emotional deprivation and also on general areas of psychology. With his wife, Dr. Ann Clarke, who is also a psychologist at The Manor, he has recently been associated with the production of a documentary film on Learning in Slow Motion relating to their research. This film has been taken over for distribu. tion purposes by the Central Office of Information.

\section{Nuclear Power Research and Development in Britain}

IN a written answer in the House of Commons on June 4, the Parliamentary Secretary for Science, Mr. D. Freeth, stated that a design team had been estab. lished to consider nuclear ships by the Atomic Energy Authority in conjunction with the British Ship Research Association and other interested organizations. The principal systems being studied by the team were the steam-cooled and steam-generating heavy-water reactors and advanced designs of pressurized-water and boiling-water reactors. Contracts for design study work had been negotiated with the Nuclear Power Group, the United Power Company, Rolls Royce and Babcock and Wilcox. Work was also in progress on reactor physics, engineering development, fuel-element technology and reactor materials in support of the marine reactor systems. In a further answer, Mr. Freeth gave the estimated cost of the experimental advanced gas-cooled reactor which should come into operation within the next two months as about $£ 9.7$ million, and tho annual outlay for the operation and maintenance of the Dounreay experimental fast reactor as at present being about $f 2$ million. On June 5 he stated that organizations for which the Minister for Science was responsible supported research in seismology by twenty-four qualified scientists, of whom twenty were employed by the Atomic Energy Authority and four were supported by research grants from the Department of Scientific and Industrial Research. The Meteorological Office employed two further scientists and the Universities of Aberdeen, Cambridge, Durham, Edinburgh and Liverpool had departments participating in seismological research.

\section{Petroleum in the United Kingdom, 1961}

United Kingdom industry statistics relating to consumption and refinery production of petroleum and its products for 1960 and 1961 was published by the Petroleum Information Bureau in April 1962, on behalf of the U.K. Petroleum Industry Advisory Committee (U.K. Petroleum Industry Statistics-Consumption and Refinery Production, 1960 and 1961. Pp. 9. London: Petroleum Information Bureau, 1962). This reveals that the internal domand for petroleum products was 7.8 per cent higher in 1961 than in the previous year, total consumption (excluding bunkers for ships engaged in foreign trade) being 46,014,950 tons. The standard products as now classified include aviation fuels, motor spirit, industrial spirits (with industrial benzole), white spirit, kerosene (burning and vaporizing oils), derv fuel, gas, Diesel and fuel oils, lubricating oils and greases, paraffin wax and scale, propane and butane, bitumen, chemical feedstock, light distillate feedstock, and refinery gases. Aviation fuels show for 1961 a $22 \cdot 3$ per cent rise; motor spirit increased by 6.8 per cent; burning oil consumption was 4.9 per cent lower, notwithstanding a rise of 50 per cent for domestic heating boilers compared with the previous year, due to the greater demand in the number of small and medium-sized houses for oil-fired central heating. Derv fuel was 9.9 per cent higher, lubricating oils only 1.5 per cent up, bitumen $9 \cdot 7$ per cent increase, and deliveries of propane and butane rose by 34 per cent, on account of heavier use in industry as gas-making feedstock. There was a rise of 11.1 per cent in consumption of refinery gases, but deliveries of chemical feedstock, which in recent years have advanced extremely rapidly, remained almost static compared with 1960 . An interesting note on tax effect on consumption of motor spirit is that the $3 d$. per gallon surcharge imposed by the 'little Budget' in July 1961 (consolidated in the 1962 Budget to produce a standard rate of duty of $2 s .9 d$. per gal.) caused a tendency for lower grades of petrol to be favoured at the expense of the super brands.

\section{U.K. Attitudes towards Population Control}

THE question of population pressure in Asia was again raised in the House of Lords by Lord Casey on June 6 , who specifically asked the Government what it proposed doing to stimulate scientific research in the United Kingdom towards a socially acceptable solution of the problem applicable to Asian conditions. Referring particularly to population growth in India and Pakistan and the introduction of family planning, Lord Casey urged the need for research into biological methods of contraception. However, other speakers in the debate, including Lord Adrian, were more cautious regarding the value of recent introductions mentioned by Lord Casey and stressed the need to consider the subject in the widest possible context, Lord Milverton expressing the view that no scientific solution of the problem could be other than an adjunct to long-term educational, economic and cultural influences. Lord Brain emphasized the same point of view, urging that the population question was not solely a matter of food for the body, and besides stressing education pointed out the risk of epidemics spreading through air travel. He suggested that careful watch should be kept for any short-term reactions in introducing new oral contraceptives and that the Government should hold a watching brief on clinical tests of all contraceptives, if they did not sponsor such tests themselves and give a lead to the World Health Organization.

In replying for the Government on the debate, the Parliamentary Under-Secretary of State for Commonwealth Relations, the Duke of Devonshire, said that the Government was well aware of the problem and he agreed as to the need to increase food supply. On scientific research, he said that research into methods of contraception was linked with research into the whole field of infertility and that both fields were closely connected with some lines of cancer research. There was no indication of a shortage of funds for any promising lines of work and there was close co-operation between scientists in Britain and in India and elsewhere. Much work on the physiology of reproduction was being undertaken in university 